\title{
天井面架構の構築順序からみた中期ビザンツ文化圈の内接十字型教会堂の展開 THE DEVELOPMENT OF THE CROSS-IN-SQUARE CHURCH DURING THE MIDDLE BYZANTINE PERIOD IN TERMS OF CEILING CONSTRUCTION PROCEDURES
}

\author{
樋口諒 ${ }^{* 1}$, 那須 聖*2 \\ Ryo HIGUCHI and Satoshi NASU
}

\begin{abstract}
This paper looks at changes over time in the construction procedure of ceilings of cross-in-square churches, one of the most common architecture in the Middle Byzantine period (9th-12th centuries), focusing on the three-dimensional characteristics of all churches within Byzantine territories. The churches are classified according to the arrangement of arches, floor plan, and the number of transverse arches on each corner bay. Two principal construction procedures are evident throughout the Middle Byzantine period: procedure likes a centralised church building and procedure likes a domed basilica building. Moreover, a mixture or hybrid of these two emerged in the 12th century.
\end{abstract}

Keywords: Byzantine Architecture, Christian Architecture, Architectural Configuration, Cross-in-Square Church, Construction Procedure ビザンツ建築, キリスト教建築, 架構構成, 内接十字型教会堂, 構築順序

\section{1. はじめに}

本研究において、ビザンツ文化圈教会堂建築 (以下、「ビザンツ建築」 と呼称する）とはビザンツ帝国の存在した期間を通じてその領土で あった地域、および一時的にビザンツ帝国の版図となりかつビザン ツ帝国同様に東方正教会の教義を信奉していた地域に建設された教 会堂群を指す。1000 年以上に亘って存続したビザンツ建築は、7〜8 世紀の一時的な建築活動の衰退期 ${ }^{1)}$ を契機として、古代ローマ建築 の延長ではないビザンツ建築固有の特質を有することになったこと が指摘されており ${ }^{2)}$ 、本研究は、この建築衰退期以降の中期ビザンツ 建築（8〜 12 世紀創建のもの）において、最も一般的かつ多様な用 途の教会堂に使用される建築形式の一つであり、ビザンツ文化圈の 広汎な地域でみられる内接十字型の教会堂に着目するものである。

中期ビザンツの内接十字型教会堂に関する既往の研究では、主に 平面的な特徵に基づいた類型学的な研究が行われてきた ${ }^{3)}$ 。しかし既 往研究では、ビザンツ文化圈における教会堂の全体を対象とはせず に限定されてた地域における教会堂を対象として、内接十字型の明 確な定義を設けずに分析をしていることもあり、平面形式の微少な 差異による類型を提示すること、もしくは既往の分類手法に分析対 象を当てはめることが目的化しており、導かれた類型や類型間の差 異に内在する建築の形態や空間、使わ㞦方などの特質については十 分に検討されていない。

このような既往研究の状況を踏まえ、前稿では既往研究に依拠し つつ、内接十字型をドームの架かった中央べイの四方のベイへ十字 状にヴォールトを配置し、その十字の隅部にさらにべイを設けるこ
とによって生じる9ベイからなる構成を有する教会堂として定義し た ${ }^{4)}$ 。その上で、中央ベイとその四方のベイよりなる十字部 (Cross-bay part) と四つのコーナーベイょりなるコーナーベイ部 (Corner-bay part) の接続構面について、建築的な形態と構法との組み合わせとしての 架構に着目し、その架構構成を中心に類型化を行い、類型間の類似 性と相違を検討して内接十字型の成り立ちに関する考察を行った。 その結果、内接十字型がこれまで捉えられてきたように単一の建築 形式ではなく、異なる二つ以上の系統を総称している可能性につい て指摘した ${ }^{5)}$ 。

一方、内接十字型における建築物内部の形態とそこから生じる空 間的な特質を捉える上では、十字部とコーナーベイ部の接続構面に おける架構構成のみならず、各べイの天井面を含む全体的な架構構 成についても検証する必要があるといえる。天井面の架構構成のう ち、コーナーベイの天井面の建築的な形態に関しては、これまでの 類型学的な研究において、内接十字型を分類する際の尺度とされて きた ${ }^{6)}$ 。しかし、天井面の形態的特徵にとどまらず、構法的な側面に まで注目した研究としては、Bourasによるリブ付きのクロス・ヴォー ルトに関する研究 ${ }^{7)}$ 以外には、ビザンツ建築の構法に関する概説書 がいくつかみられるのみである ${ }^{8)}$ 。また、内接十字型における天井面 架構に関する研究としては、二円柱式とよばれる中央のドームべイ の各隅に配される四本の柱（以下、隅部柱）のうち、西側の二本の み円柱を用いる建築類型の内接十字型を対象として、コーナーベイ の天井面架構が教会堂の内部と外部におけるプロポーションを適正 なものとするために変化してきた可能性を指摘した M amaloukos の研
*1 東京工業大学大学院 博士後期課程 - 修士 (工学) / 日本学術振興会特別研究員 DC

$* 2$ 東京工業大学環境・社会理工学院建築学系 准教授・博士 (工学)
Doctoral Course, Tokyo Institute of Technology, M.Eng. Assoc. Prof., Tokyo Institute of Technology, Dr.Eng. 


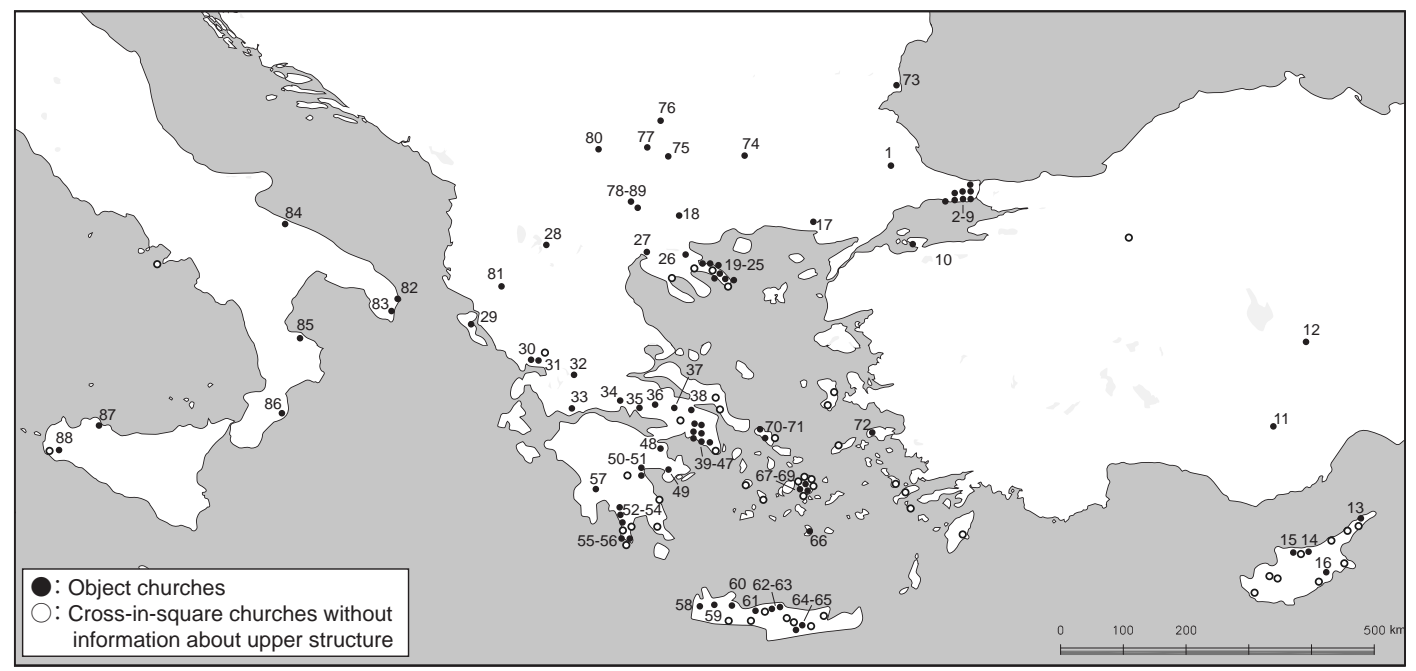

Fig. 1 Location of cross-in-square churches from the Middle Byzantine period

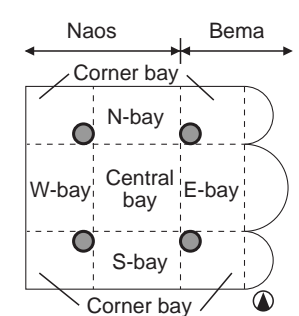

a. Church with 9 bays

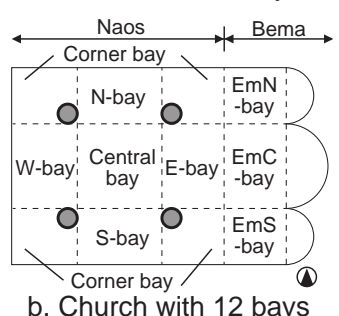

Fig. 2 Names of specific bays
究があげられる ${ }^{9)}$ 。この二円柱式の内接十字型は、11 世紀以降のビ ザンツ文化圈のバルカン半島およびペロポネソス半島において、し ばしばみられる形式ではあるものの、その発生過程については様々 な議論がされてきた。例として、当該建築類型をドームべイの四隅 に全て円柱を用いる内接十字型のうち、バルカン半島東部からコン スタンティノープルにかけての地域で多くみられる 12 ベイから構成 される内接十字型教会堂の東側の 3 ベイが省略されたものと措定し た K rautheimer ${ }^{10)}$ 、反対にバルカン半島南部からペロポネソス半島に かけての地域に多く見られる 9 ベイから構成される内接十字型教会 堂が起源であると措定している M amaloukas ${ }^{11)}$ 、および創建時におけ る円柱の調達容易性と関連付けている Ćurčićín ${ }^{12)}$ の仮説などがあげら れる。しかしいずれの研究者も、二円柱式内接十字型とそれ以前か ら存在する内接十字型の関係性について十分検討しているとは言い がたい。この二円柱式内接十字型の起源に関する上述の既往研究に 代表されるように、これまでの研究では、8 世紀末に発生したといわ れる内接十字型 ${ }^{13)}$ が中期ビザンツ期の間にどのように変化し、展開 してきたかについては、ほとんど検討されていない。僅かにみられ る研究にしても、一部の教会堂をもとにビザンツ建築全体の発展と 展開を推定しているもの ${ }^{14)}$ 、ないし Ćurčić のように ${ }^{15)} 、 20$ 世紀の後 半にはすでに否定された ${ }^{16)}$ ビザンツ建築の建築形式が直線的に発展 を遂げたという推論、即ちバシリカ形式からドームバシリカ形式と なり、クロス・ドームド形式を経て内接十字型となったという 20 世 紀前半の推論 ${ }^{17)}$ に自覚的・非自覚的に多くを拠っている。

このような背景をもとに本稿では、天井面全体を含む内接十字型 教会堂内部の上部架構の構成について ${ }^{18)}$ 、どのように教会堂を構築 するかという点に着目して類型化を行った上で、形態と構法の組み 合わせとしての架構の観点から類型同士の相互関係について検討す ることにより、中期ビザンツ内接十字型の展開について考察するこ とを目的とする。その際に、前稿にて導かれた二つの系統が、隅部 柱の上に載るアーチ（以下、上部アーチ）の高さ関係の差異、即ち上 部アーチの配列形式の差異によるものであることを踏まえ、本稿で も上部アーチの配列形式に着目しつつその展開について考察を行う。

なお本稿では、中期ビザンツ文化圈内接十字型教会堂のうち、上 部架構が現存し検討可能と考えられる 124 棟の中から ${ }^{19)}$ 、現地調査
などによって教会堂の情報を得られた教会堂 88 棟を対象遺構とす る (Fig. 1: 1〜 88, Table 1) ${ }^{20)}$ 。また、対象遺構の検討にあたり本稿 では、内接十字型教会堂の主要な部位たるナオスとべマの各部につ いて ${ }^{21)}$ 、次のように呼称する。教会堂の主たる部分が 9 ベイからな る場合、中央のドームを冠したべイを中央べイ（Central bay）、その 東西南北に隣接するべイをそれぞれ東西南北べイ（北べイ：N-bay、 南べイ：S-bay、東べイ：E-bay、西ベイ：W-bay、東西南北べイ： NSEW-bay)、残りをコーナーベイ（Corner bay）とし西側の 6 ベイ がナオス (Naos)、東側の 3 ベイがベマ(Bema) である(Fig. 2-a)。一方、 主たる部分が 12 個のベイからなる場合、先述の 9 つのベイの東側に 付随する 3 つのべイを東端 3 ベイとし、北から東端北べイ (EmN-bay)、 東端中央べイ (EmC-bay)、東端南ベイ (EmS-bay) と呼称し、西側の 9 ベイがナオス、東側の 3 ベイがベマである (Fig. 2-b) 22 。

本論の構成の概略を示す。 2 章では、対象遺構の天井面の架構を通 覧し、形態的な特徵について把握する。3 章では、対象遺構 88 棟に ついて、その上部アーチの配列形式および各コーナーベイにおける 横断アーチの使用数およびナオスとべマのべイ数に着目して類型化 を行う。4 章では抽出された各類型における形態と天井面架構の構築 順序との関係性に着目してそれぞれの特徵を明らかにし、架構的な 特質から中期ビザンツ内接十字型の展開について考察を行う。

\section{2. 内接十字型教会堂における天井面架構の架構要素}

本章では、対象遺構の天井面をその形態および構築方法の差異に よって分節し、それらを架構要素と位置付けた上で、それぞれの架 構要素について、その形態および使用場所について説明する ${ }^{23)}$ 。対 象遺構においては、面的な架構要素として、ドーム (Dome)、ペンデ ンティヴ (Pendentive)、スクィンチ (Squinch)、半ドーム (Conch)、 バレル・ヴォールト (Barrel vault)、四半円ヴォールト (Half barrel vault)、クロス・ヴォールト (Cross vault)、斜交ヴォールト (Diagonal intersecting vault)、ドーム・ヴォールト (Domical vault) の 9 つがあ げられ、線的な架構要素として、アーチ (Arch) があげられる ${ }^{24)} 。$

ドーム (Fig. 3-a)、ペンデンティヴ (Fig. 3-b)、スクィンチ (Fig. 3-c)

ドームは、半球状の曲面による面的な架構であり、ドラムと呼ば 

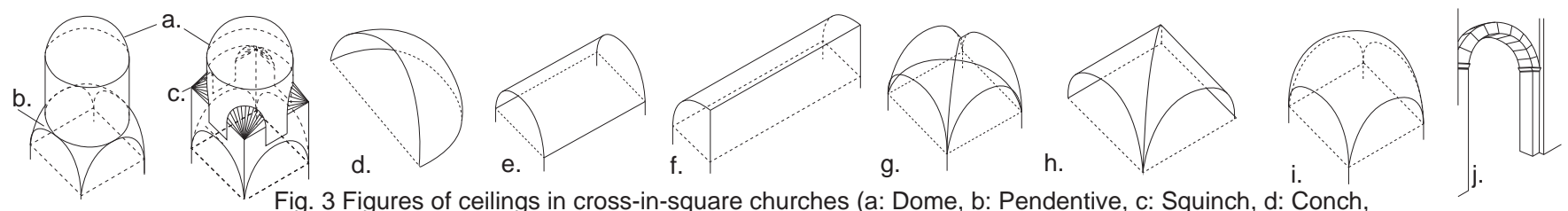

e: Barrel Vault, f. Half barrel vault, g. Cross vault, h. Diagonal intersecting vault, i: Domical vault, j: Arch)

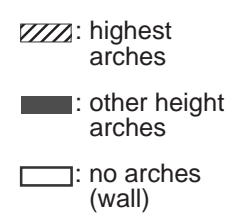
wall)
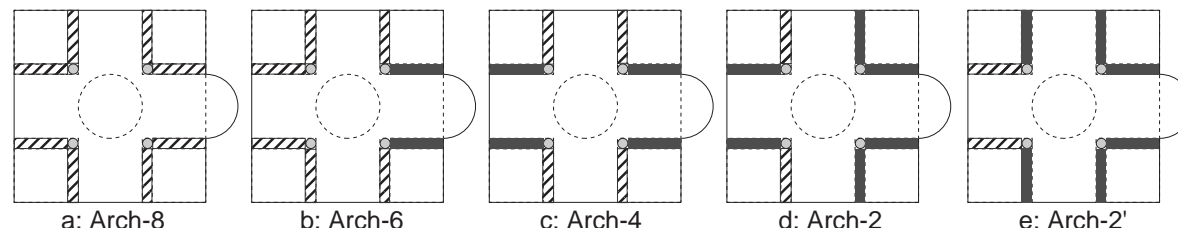

e: Arch-2'

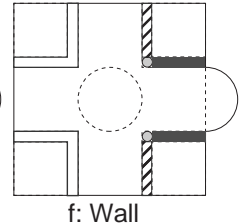

f: Wall

Fig. 4 Arrangement of the arches and the number of the highest arches

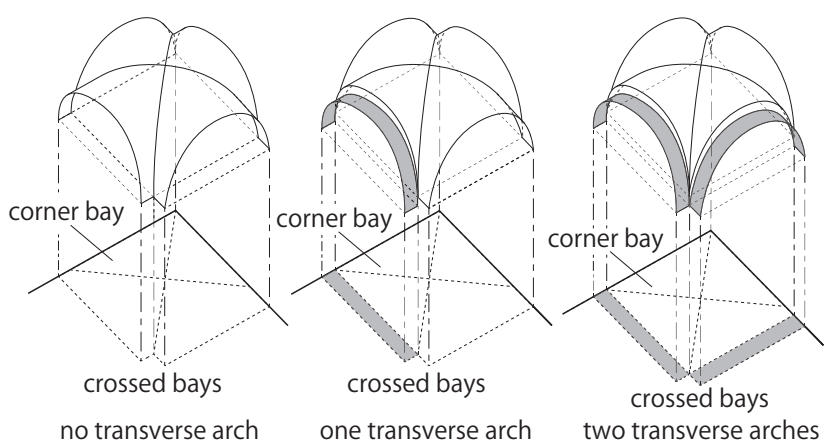

Fig. 5 Number of transverse arches

れる円筒状の部位の上に載る。四角形のベイの上部に円形断面のド ラムを載せる際に、ベイの各隅に曲面三角形よりなる面的な架構を 設けるのがペンデンティヴであり (Fig. 3-b)、ベイの各隅に半円錐状 の架構を設け、その上部を多角形に変換するための面的な架構がス クィンチである (Fig. 3-c)。ドームは、対象遺構の中央ベイには必ず 設けられ、教会堂の天井面のうち最も高い場所となる。Palermo(87) とDelia(88) 以外の遺構では、ドラムの上にドームが載り、ドラム はペンデンティヴを介して東西南北ベイ上部の天井面架構と接続し ている。一方、Palermo(87) では、ドームはドラムの上に載り、ス クィンチを介して東西南北べイ上部の天井面架構と接続している。 Delia(88) では、ドームはスクィンチの上に直接載り、スクィンチを 介して東西南北べイ上部の天井面架構と接続している。また中央べ イ以外にも、Pherrai(17) のように、各コーナーベイの天井面にも使用 され、この場合もペンデンティヴが使用される。

半ドーム (Fig. 3-d)

半ドームは、四半球形状の曲面による面的な架構である。べマの 三つのベイそれぞれの東端の半円部分の天井面となる ${ }^{25)}$ 。

バレル・ヴォールト (Fig. 3-e)

バレル・ヴォールトは、円筒状の曲面による面的な架構である。 M yrelaion(4) 以外の教会堂では、十字部の天井面として使用されてい る他、コーナーベイおよび東端 3 ベイの天井面としても用いられる。 四半円ヴォールト（Fig. 3-f）

四半円ヴォールトは、四半円断面のヴォールトによる面的な架構 である。Panagias K atholikon (48) の西側のコーナーベイの天井にのみ 認められる。

クロス・ヴォールト Fig. 3-g)

クロス・ヴォールトは、二つの半円形断面のヴォールトが互いに
直角に相貫することで形成される形状からなる面的な架構である。 対象遺構の多くでは、コーナーベイおよび東端 3 ベイの天井面とし て使用される。Myrelaion(4) では、十字部の天井面架構としても使 用される。

斜交ヴォールト (Fig. 3-h)

斜交ヴォールトは、二つの半円形断面のヴォールトが対角線上で 相貫することによって形成される形状からなる面的な架構である。 Chalki Geōrgios(67) のコーナーベイにおいてのみ使用が認められる。

ドーム・ヴォールト (Fig. 3-i)

ドーム・ヴォールトは、ドーム同様に、天井面が半円球状となる ものであるが、ドームとは異なり、べイの各隅に使用されるペンデ ンティヴの曲率がドームと等しく、従ってペンデンティヴからドー ムまでが連続した曲面となるものである。コーナーベイおよび東端 南北ベイの天井面に使用される。

アーチ (Fig. 3-j)

アーチは、円筒状の曲面による天井面の架構のうち、バレル・ヴォー ルトとは異なり、線的な架構と見做せるものを指す。主に、十字部 とコーナーベイ部の接続部において上部アーチとしてみられる他、 コーナーベイと外壁との間にブラインドアーチとして、アーチが設 けられることもある。

内接十字型における、天井面架構を構成する要素は以上のように なる。本稿では十字部とコーナーベイ部の接続部において用いられ、 特にコーナーベイとは非連続の形態となるアーチについて横断アー チ（TransverseArch）と呼ぶ。

\section{3. 天井面架構の架構要素の組み合わせ}

内接十字型の教会堂では、全ての遺構が天井面の最頂部に至るま で組積造となる。従って、それぞれの教会堂における天井面架構の 架構要素の上下関係より建築部位の施工の順序を捉えることができ る ${ }^{26)}$ 。また、これらの遺構において、十字部の入隅部にペンデンティ ヴないしスクィンチを配置することによって、東西南北べイの天井 面架構とドラムを接続し、ドラムの上にドームを架けるという点は 共通している。従って、内接十字型における施工順序の違いは、外 壁面および隅部柱より、東西南北べイの天井面までをどのように構 築するか、換言すれば、東西南北ベイとコーナーベイ、および東端 3 ベイが存在する場合にはこれら 3 ベイも含めての構築順序の違いを 把握すればよいことになる。その上で、コーナーベイの天井面はし 
Table 1 Categories of classification and typology by architectural configuration

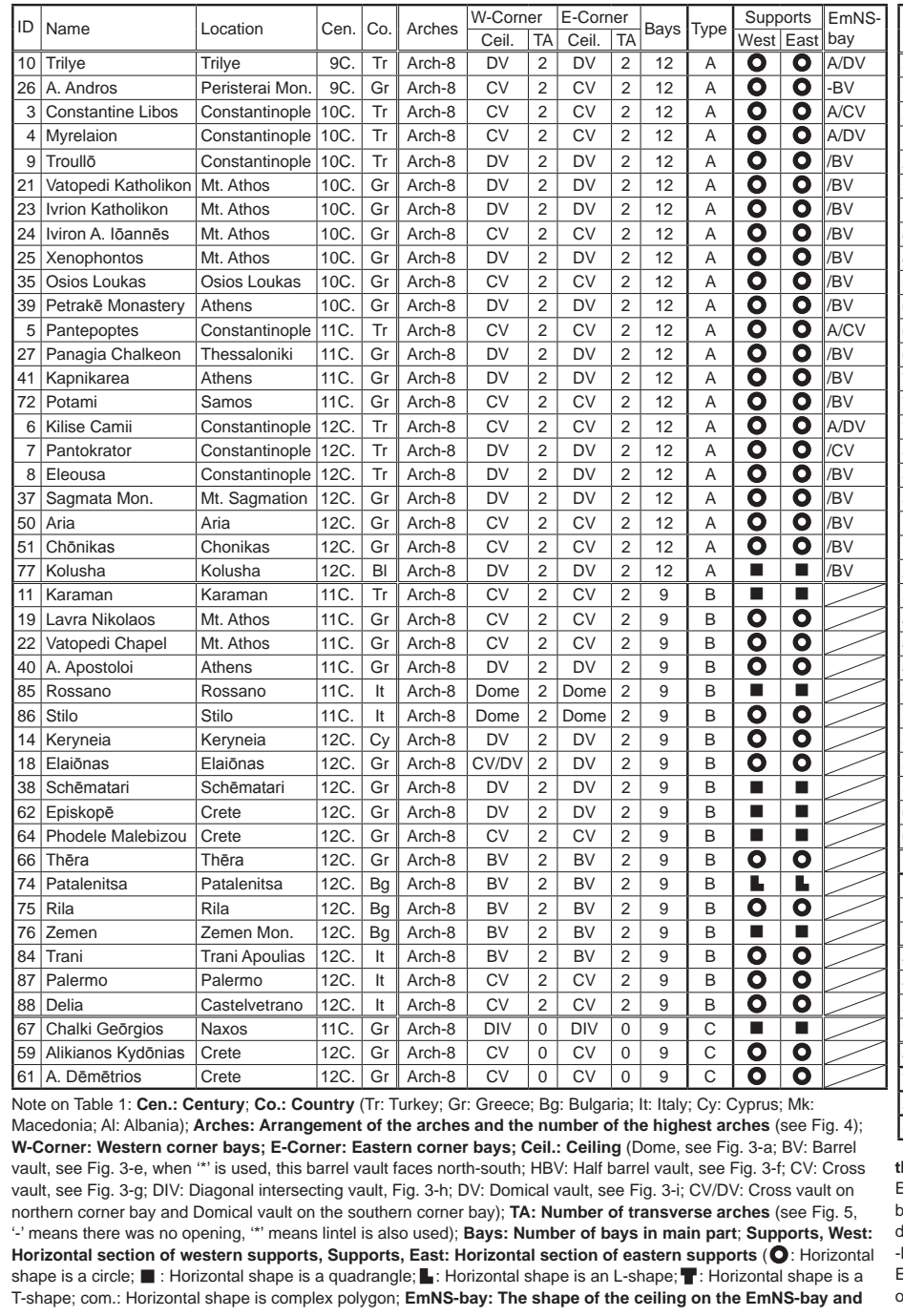

\begin{tabular}{|c|c|c|c|c|c|c|c|c|c|c|c|c|c|c|}
\hline & \multirow{2}{*}{\begin{tabular}{|l|} 
Name \\
Arta A. Dimitōrios
\end{tabular}} & \multirow{2}{*}{\begin{tabular}{|l|l|} 
Location \\
Arta
\end{tabular}} & \multirow{2}{*}{\begin{tabular}{|l|} 
Cen. \\
$9 \mathrm{C}$.
\end{tabular}} & \multirow{2}{*}{\begin{tabular}{|c|} 
Co. \\
$G r$
\end{tabular}} & \multirow{2}{*}{ Arches } & & & \multicolumn{4}{|c|}{ ys $\frac{\text { W-Corner }}{\text { W-Corner. }}$} & \multicolumn{3}{|c|}{\begin{tabular}{|l|l|} 
Type & Supports \\
West|Fast
\end{tabular}} \\
\hline & & & & & & & 9 & BV & & $\begin{array}{l}\text { Ceil. } \\
\text { By } \\
\end{array}$ & ITA| & $\mathrm{D}$ & twest & $T$ \\
\hline & & Evrytania & $\frac{9 c}{9 c}$ & $G$ & Arc & & 9 & $\mathrm{BV}$ & 1 & BV & 1 & \begin{tabular}{|l|l|l|l|l}
$D$ & \\
\end{tabular} & ! & 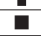 \\
\hline & Skripou & Skripou & 90 & G & Arc & & 9 & BV & 1 & BV & & $\mathrm{D}$ & & 口 \\
\hline & Kellia & Kellia & 100 & C) & & & 9 & BV & 1 & BV & 1 & D & $=$ & E \\
\hline & Prespa & Prespas & 100 & $G$ & & & 9 & BV & 1 & BV & 1 & $\mathrm{D}$ & $\bar{a}$ & $\bar{\square}$ \\
\hline & Gavrolomnē & Gavrolomnē & 100 & $G$ & Arc & & 9 & $\mathrm{BV}$ & & $\mathrm{BV}$ & 1 & $\mathrm{D}$ & $\bar{a}$ & $\bar{\square}$ \\
\hline & Kaynarca & Kaynarca & $11 \mathrm{C}$ & Tt & Arc & & 9 & BV & & BV & 1 & $\mathrm{D}$ & - & 口 \\
\hline & A. Asōmatioi & Athens & 110 & G & Arc & & 9 & BV & 1 & BV & 1 & $\mathrm{D}$ & & 0 \\
\hline & A. Theodoroi & Athens & $11 \mathrm{C}$ & G & Arc & & 9 & BV & & BV & 1 & $\mathrm{D}$ & - & 口 \\
\hline & Vambaka & Vambaka & 110 & G & ArC & & 9 & BV & & BV & 1 & \begin{tabular}{|l|l} 
\\
\end{tabular} & 0 & \# \\
\hline & Stylos Apokorōnou & Crete & 110 & G & Arc & & 9 & $\mathrm{BV}$ & & BV & 1 & ( & $=$ & $\bar{\square}$ \\
\hline & Chalki Prōtothronos & Naxos & $11 \mathrm{C}$ & G & Arc & & 9 & BV & 1 & BV & & $\mathrm{D}$ & E & 口 \\
\hline & Potamia & Naxos & $11 \mathrm{C}$ & G & Arc & & 9 & BV & 1 & BV & 1 & $D$ & a & E \\
\hline & Mesembria & Mesembria & $11 \mathrm{C}$ & $\mathrm{BC}$ & Arc & & 9 & BV & & BV & 1 & $\mathrm{D}$ & - & 口 \\
\hline & Vodoča older & Vodoča & 110 & $M$ & Arc & & 9 & $\mathrm{BV}$ & & BV & ( & $\mathrm{D}$ & $\bar{\square}$ & $\bar{\square}$ \\
\hline & Vodoča newer & Vodoča & 110 & $\mathrm{M}$ & Arc & & 9 & BV & & BV & 1 & 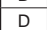 & - & $\bar{a}$ \\
\hline & Peshkëpi & Peshk & 110 & A & & & 9 & $\mathrm{BV}$ & 1 & BV & 1 & $\mathrm{D}$ & - & $\bar{\square}$ \\
\hline & Otranto & Otranto & 110 & It & Arc & & 9 & BV & & BV & & $\mathrm{D}$ & $\overline{0}$ & o \\
\hline & Castro & Castro & 110 & It & Arc & & 9 & $\mathrm{BV}$ & 1 & BV & 1 & \begin{tabular}{|c|}
$\mathrm{D}$ \\
\end{tabular} & 0 & 0 \\
\hline & Rizokarpaso & Rizokarpaso & $12 C$ & C) & Arc & & 9 & BV & & BV & 1 & D & - & 口 \\
\hline & Lambousa & Lambousa & $12 C$ & C) & Arc & & 9 & BV & & BV & 1 & \begin{tabular}{|l|l|}
$D$ \\
\end{tabular} & $\bar{\square}$ & a \\
\hline & Kerkyra & Kerkyra & $12 C$ & G & Arc & & 9 & BV & 1 & \begin{tabular}{|l|l|} 
BV \\
\end{tabular} & 1 & \begin{tabular}{|l|l|l|l|l|l}
$D$ & \\
\end{tabular} & 0 & 口 \\
\hline & Arta A. Nikolaos & Arta & $12 C$ & $G$ & & & 9 & $\mathrm{BV}$ & 1 & BV & 1 & $\mathrm{D}$ & 0 & ! \\
\hline & Kaisariani Katholikon & Mt. Hymettos & $12 C$ & $G$ & & & 9 & BV & & BV & & $\mathrm{D}$ & 0 & 0 \\
\hline & Metamorphosē & Athens & $12 C$ & $\mathrm{G}$ & & & & BV & & BV & & \begin{tabular}{|l|l|}
$D$ \\
\end{tabular} & 0 & 0 \\
\hline & Gorgoepēkoos & Athens & $12 C$ & $G$ & & & 9 & BV & & BV & 1 & $\mathrm{D}$ & 0 & 0 \\
\hline & Kastania & Kastania & $12 c$ & $G$ & & & 9 & BV & & BV & & $\mathrm{D}$ & 0 & 0 \\
\hline & Nomitzi & Nomizi & $12 C$ & $G$ & & & 9 & $\mathrm{BV}$ & & BV & & $\mathrm{D}$ & 0 & 0 \\
\hline & Kyriakê & Agia Kyriakē & $12 C$ & $G$ & Ars & & 9 & $\mathrm{BV}$ & 1 & BV & & D & 0 & a \\
\hline & Kitta & Kitta & 120 & $G$ & & & & $\mathrm{BV}$ & 1 & BV & 1 & D & 0 & $\mathbf{0}$ \\
\hline & Latziana Kisamou & Crete & $12 C$ & $G$ & & & & BV & & BV & & & & 0 \\
\hline & Partira & Crete & $12 c$ & $G$ & & & & BV & & BV & & & & \\
\hline & Ligortys & Crete & $12 c$ & G & & & 9 & BV & & BV & 1 & 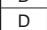 & 0 & $\overline{0}$ \\
\hline & Çanlı kilise & Hassan dağ & 110 & $T$ & & & 9 & BV & 2 & BV & 2 & $\mathrm{E}$ & I & $\bar{\pi}$ \\
\hline & Atik Mustafa Paşa & Constantinople & 90 & $T$ & & & & BV & & BV & 2 & $\mathrm{~F}$ & $\mathbf{L}$ & 5 \\
\hline & Pherrai & Pherrai & $12 C$ & $\mathrm{G}$ & & & Th & Dome & & Dom & 2 & & & \\
\hline & Amphissa & Amphissa & $12 C$ & $G$ & & & 9 & DV & & $\mathrm{CV}$ & & & & \\
\hline & A. Iōannēs Theologos & Athens & $\frac{120}{120}$ & $\frac{10}{.6}$ & $\mathrm{ArC}$ & & $\frac{3}{9}$ & $\mathrm{BV}^{*}$ & & BV & $\frac{2}{1}$ & $\frac{1}{G G}$ & 0 & E \\
\hline & Panagia & Panagias Mon. & 120 & $G$ & & & 9 & HBV & & BV & & 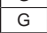 & 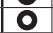 & a \\
\hline & Samari & Samari & 120 & & & & 9 & DV & & BV & & $G$ & O & E \\
\hline & Melida & Andros & 120 & G & & & 9 & $\mathrm{cV}$ & & BV & 1 & G & 0 & $\bar{\square}$ \\
\hline & Lygourio & Lygourio & 120 & $\bar{G}$ & & & 9 & $\mathrm{cV}$ & & $\mathrm{BV}$ & & $\mathrm{H}$ & 0 & $\bar{\square}$ \\
\hline & Mesaria & Andros & $\frac{120}{12 C}$ & & & & $\frac{3}{9}$ & $\mathrm{BV}$ & & DV & $\frac{1}{2}$ & $\frac{1}{1}$ & \begin{tabular}{|l}
0 \\
\end{tabular} & a \\
\hline & Lavra Kat & Mt. Atho & $110 \mathrm{C}$ & & & & 9 & $\mathrm{cV}$ & & DV & & $\mathrm{J}$ & & \\
\hline & Nerezi & Nere & & & & & & & & & & & L & a \\
\hline
\end{tabular}

the height relationship of the ceiling on the eastern corner bays and the EmNS-bay (BBV: Ceilings of EmNS-bays are barrel vaults and connect directly to the ceilings of the eastern corner bays: ceilings of EmNSbays are under the ceilings of the corner bays; / CV: Ceilings of EmNS-bays are cross vaults and connect

directly to the ceilings of eastern corner bays: ceilings of EmNS-bays are under the ceilings of the corner bays; -BV: Ceilings of EmNS-bays are barrel vaults and do not connect to the eastern corner bays; A/CV: Ceilings of EmNS-bays are cross vaults and connect to the ceilings of the eastern corner bays via arches; AVDV: Ceilings of EmNS-bays are domical vaults and connect to the ceilings of the eastern corner bays via arches)

ばしば上部アーチの上に直接載ること、および前稿にて最も高い位 置に配置される上部アーチの位置関係の違いが内接十字型の異なる 二つの成り立ちを示していたことから ${ }^{27)}$ 、本稿においても最も高い 上部アーチの位置についても着目する。

まず、上部アーチの配列形式については、全ての上部アーチが同 じ高さに配列される Arch-8 型（Fig. 4-a)、隅部柱から南北方向およ び西側へ架かる計六本の上部アーチが一番高くなる Arch-6 型 (Fig. 4-b)、隅部柱から南北へ架かる上部アーチが一番高くなる Arch-4 型 (Fig. 4-c $)^{28)}$ 、西側の隅部柱から南北へ架かる上部アーチが一番高く なるArch-2 型 (Fig. 4-d)、西側の隅部柱から西へ架かる上部アーチ が一番高くなる Arch-2' 型 (Fig. 4-e) および西側のコーナーベイ部と 十字部に開口が設けられず、東側の隅部柱から南北へ架かる上部アー チが一番高くなるWall 型である（Fig. 4-f)。

また構築順序を左右するものとして、横断アーチの有無があげら れる。なぜならば、ベイ間に横断アーチを設ける場合、横断アーチ を挟む二つのべイは別々に構築可能なのに対し、横断アーチが存在 しない場合、二つのべイは低い方の天井面を構築した後に、高い方 の天井面を構築したものと考えられるからである。そこで、各コー ナーベイと東西南北べイとの接続面における横断アーチの使用個数 を見たところ、横断アーチを二つ使用する場合、一つ使用する場合 および全く使用しない場合の三種類がみられた (Fig. 5)。

これら以外に遺構の構築順序に違いを生じさせ得る要素として、 教会堂の検討対象部位のベイ数、即ち東端 3 ベイが存在するかがあ げられる。Fig. 2 のように対象遺構には、9ベイのものと 12 ベイのも のがみられる。

以上について纏めたものが Table 1 である。表から 11 の類型を識 別でき、それらにA から K までの記号を付した。各類型の具体的な 分類結果について、上部アーチの配列、西側のコーナーベイの横断 アーチの個数、東側のコーナーベイの横断アーチの個数、全体のべ

イ数および該当する遺構数の順に以下に示す

Type-A: Arch-8 型、2 横断アーチ、2 横断アーチ、12 ベイ（22 棟） Type-B: Arch-8 型、2 横断アーチ、2 横断アーチ、9 ベイ（18 棟） Type-C: Arch-8 型、0 横断アーチ、0 横断アーチ、9 ベイ（3 棟） Type-D: Arch-4 型、1 横断アーチ、1 横断アーチ、9ベイ（33 棟） Type-E : Arch-4 型、2 横断アーチ、2 横断アーチ、9 ベイ（1 棟） Type-F : Arch-6 型、2 横断アーチ、2 横断アーチ、9ベイ（3 棟） Type-G : Arch-6 型、2 横断アーチ、1 横断アーチ、9 ベイ（4 棟） Type-H: Arch-6 型、0 横断アーチ、1 横断アーチ、9 ベイ（1 棟） Type-I: Arch-2 型、1 横断アーチ、2 横断アーチ、9 ベイ（1 棟） Type-J : Arch-2' 型、2 横断アーチ、1 横断アーチ、9 ベイ（1 棟） Type-K: Wall 型、0 横断アーチ（壁）、2 横断アーチ、9ベイ（1 棟） 


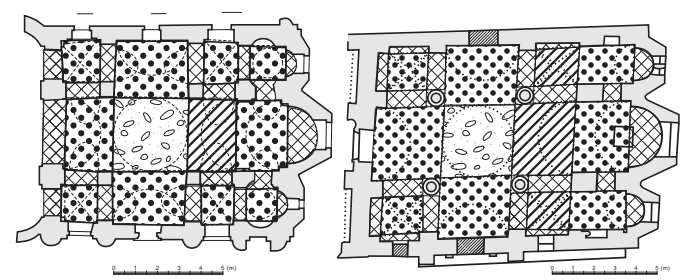

a. Myrelaion(4; Type-A) b. Osios Loukas(35; Type-A) c. Stilo (86; Type-B)

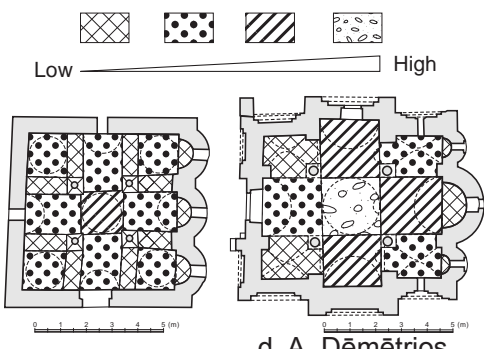

(61; Type-C)

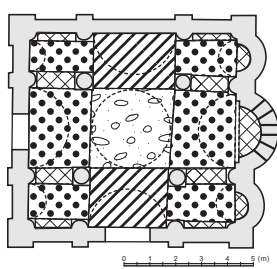

e. Otranto (82; Type-D)

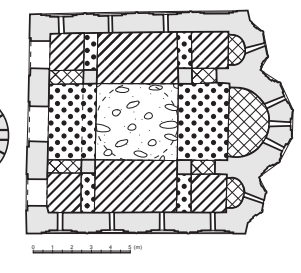

f. Çanlı Kilşise (12; Type-E) Fig. 6 P rocedure of ceiling construction (Type-A-D)

\section{4. 架構形式からみた内接十字型教会堂の特質と経年的な変化}

本章では、抽出された各類型における形態と構築順序の関係性に 注目してそれぞれの特徵を明らかにし、架構としての特質から内接 十字型の展開について考察を行う。なお各類型の形態的特徵を捉え るために、対象遺構の各コーナーベイの天井面架構および隅部柱の 断面形状 (Supports, West/East) に着目し ${ }^{29)}$ 、構築順序を捉えるとい う視点から、東端 3 ベイが存在する場合については、東端南北べイ の天井面架構と東側のコーナーベイの天井面架構との上下関係にも 着目し、これらをTable 1 の右端に纒めている。

\section{4-1. 架構形式からみた各類型の特質}

Arch-8 型 (Type-A-C) :

12 ベイとなるのは Type-A のみである。Type-A の 22 棟の遺構では、 全遺構の全てのコーナーベイにおいて、十字部との接続部に二つの 横断アーチが用いられ、Type-B の遺構 18 棟でも、全てのコーナー ベイにおいて、十字部との接続部に二つの横断アーチが用いられて いる。Type-C の遺構 3 棟では、十字部とコーナーベイ部の接続部に 横断アーチは用いられない。コーナーベイの天井面の架構要素に着 目すると、Type-A の全遺構、Type-C の全遺構、およびType-B の遺 構のうち Elaiōnas(18) を除く 17 棟では 4 つのコーナーベイに共通し て同じ架構要素が用いられ、Elaiōnas(18) では 4つのコーナーベイの うち、北西コーナーベイのみクロス・ヴォールトを用い、それ以外 の 3 ベイはドーム・ヴォールトを用いている。Type-A-C の遺構にお けるコーナーベイの天井面架構の内訳を見ると、クロス・ヴォール トを使用している遺構が 19 棟およびドーム・ヴォールトを使用して いる遺構が 17 棟であり、バレル・ヴォールトを使用している遺構が 5 棟、ドームを使用している遺構が 2 棟、斜交ヴォールトを使用して いる遺構が 1 棟みられる。Type-A の遺構はドーム・ヴォールトを用 いているものが 12 棟、クロス・ヴォールトを用いているものが 10 棟であり、それ以外の架構要素は認められない。Type-B の遺構は、ドー ム・ヴォールトを用いている遺構が 5 棟、クロス・ヴォールトを用 いている遺構が 7 棟であり、バレル・ヴォールトを用いている遺構 が 5 棟、ドームを使用している遺構が 2 棟である。Type-C の遺構は クロス・ヴォールトを用いているものが 2 棟、斜交ヴォールトを用 いているものが 1 棟である。なお、Arch-8 型の遺構では、隅部柱の 断面形状は、全て東西で同じ形状となる。断面形状が円形となる遺 構は Type-A-C において、9 世紀から 12 世紀を通じてみられるのに 対し、矩形となる遺構は Type-A-C の 11 世紀以降の遺構にしかみら れない。また、Kolusha(77) を除いたType-A の教会堂では、柱の断 面形状が円形となるのに対し、9ベイとなる Type-B-C の教会堂で柱
の断面形状が円形となるのは、21 棟中 13 棟にとどまる。

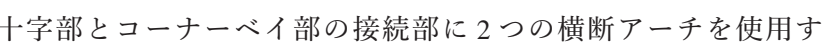
る Type-A の遺構について、隣接するべイ同士の天井面架構の構築 順序に着目すると、大きく二つにわけられる。すなわち Fig. 6-aの M yrelaion(4) のように、まず横断アーチ、東側のコーナーベイと東 端の南北ベイとの間のアーチ、および東端の半ドームを構築し、そ の後にコーナーベイと十字部の天井面を別々に構築したものと、 Fig. 6-b の Osios Loukas(35) のように、横断アーチと東端の半ドーム をまず構築し、続いて西側のコーナーベイと南北西ベイ、東端 3 ベ イを別々に構築し、さらに東べイと東側のコーナーベイを構築した ものである。一方、Type-B の遺構では、まず東側のコーナーベイと 東端の半ドームを構築し、その後にコーナーベイと十字部の天井面 を別々に構築したものと考えられる(Fig. 6-C)。Type-A-B のいずれ の場合にも、十字部・東端中央ベイとコーナーベイ部・東端南北べ イ、ないし十字部とコーナーベイが個別に構築された可能性を指摘 でき、十字の各隅にそれぞれべイを設けたものともいい得る（以下、 十字式構築 : Cruciform Construction)。一方、横断アーチを使用しない Type-C の遺構では、西側のコーナーベイと東端の半ドームを構築し たのち、東側のコーナーベイと西べイを構築し、南北東べイを構築 したものと考えられる (Fig. 6-d)。このような構築順序となる場合を 集中式構築（Centralised Construction）とする。

ここで、12 ベイとなる Type-A の遺構は 9 世紀から 12 世紀までみ られるのに対し、9ベイとなる Type-B-C の遺構は 11 世紀以降にし かみられないことを考慮にいれると、9ベイとなる内接十字型の教会 堂は、12 ベイの教会堂の東端 3 ベイを省略した結果生じたものであ ると捉えられる。加えて、Type-A では全てのコーナーベイの天井面 が同じ架構要素となりかつクロス・ヴォールトかドーム・ヴォール トしかみられず、コーナーベイと十字部との間には常に横断アーチ が二つ使用されたのに対し、Type-B-C ではコーナーベイの天井面に クロス・ヴォールトとドーム・ヴォールトを含む 5 つの架構要素を 用い、かつ 4 つのコーナーベイ全てが同じ架構要素とならない遺構 がみられる。加えて 9 ベイでは横断アーチが全くみられない遺構も みられるようになる。以上を踏まえると、Type-A からは窅える内接 十字型の一定の架構構成が Type-B-C では崩れつつあるともいえる。 Arch-4 型 (Type-D-E):

Type-D-E の遺構は 34 棟あり、前者が 33 棟で 9 世紀から 12 世紀 までみられ、後者は 11 世紀の 1 棟のみである。これらの全ての遺構 では、コーナーベイの天井面がバレル・ヴォールトとなり、Type-D では各コーナーベイにおいて十字部とコーナーベイ部の接続部のう ちコーナーベイと東西の十字の腕の接続面にのみ横断アーチが架か 


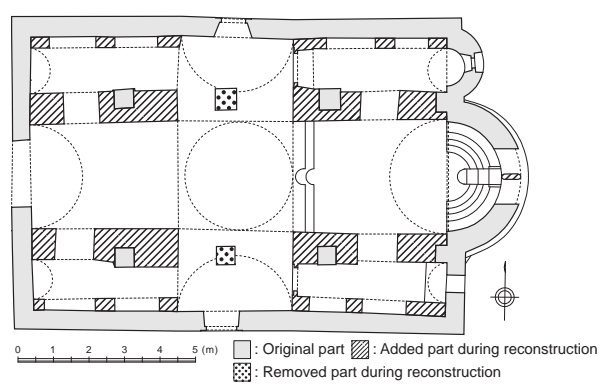

Fig. 7 Construction phase of Chalki Prōtothronos(68)

り、Type-E では各コーナーベイに二つの横断アーチが使用される。 また、Type-D-E の遺構のうち 28 棟では隅部柱は全て同じ断面形状 となり、Type-E の遺構を含む 17 棟が矩形断面 ( 9 〜 12 世紀 )、10 棟 が円形断面 (11〜 12 世紀)、1 棟が 丁 字断面 (9 世紀) となる。対して、 西側の柱が円形となり東側の柱が矩形となる教会堂も 11 世紀以降に 6 棟みられる。

Type-D の遺構の天井面の構築順序をみてみると、Fig. 6-e にある ように、まず東西ベイとコーナーベイ部の接続部の横断アーチおよ び東端の半ドームを構築し、その後にコーナーベイと東西べイの天 井面を設け、南北べイはコーナーベイを構築したのちに天井面が架 かるものとなる。一方 Type-E では、まず東西方向に架かる横断アー チと東端の半ドームを構築し、続いて東西の天井面と南北方向に架 かる横断アーチを設け、コーナーベイと南北べイはその後に架かる。

Arch-4 型の遺構のように、南北方向に架かるバレル・ヴォールト が三つ南北に連なり、その中央のべイの天井高がもっとも高くなる 点は三廊式バシリカを想起させ、Type-D では南北べイの天井面と なる東西方向に架かるヴォールトがコーナーベイの天井面架構の上 に構築され、Type-E においても南北べイの天井面のヴォールトは横 断アーチを介してはいるものの、コーナーベイよりも高くなってい る点を踏まえれば、これらの教会堂では、三廊式バシリカの側廊の 中央部のヴォールトを $90^{\circ}$ 回転させかつ高さを調整することによっ て、十字状にバレル・ヴォールトを配置し、その交点にドームを設 けたものと捉えられる。事実、Chalki Prōtothronos (68) の教会堂 (Fig. 7）では、もともと三廊式のヴォールト天井のバシリカであった教会 堂が、11 世紀にドームが設けられ内接十字型となったことが確認さ れている ${ }^{31}$ 。以上を踏まえ、以降このような構築順序となる場合を ドームバシリカ式構築 (Dome Basilica Construction) とする。

Arch-6 型 (Type-F-H) :

Type-F の遺構は 3 棟あり、9 世紀のものが 1 棟、12 世紀のものが 2 棟である。Type-G の遺構は 4 棟あり、いずれも 12 世紀のものである。 Type-H の遺構は、12 世紀に創建された 1 棟である。Type-F では十 字部とコーナーベイの接続部に 2 つの横断アーチを設け、Type-G では西側のコーナーベイには二つの横断アーチを設け、東側のコー ナーベイには一つの横断アーチを設けており、Type-Hでは西側の コーナーベイには横断アーチを設けず、東側のコーナーベイに横断 アーチを一つだけ設けている。Type-F の天井面架構をみると、A tik M ustafa Paşa (2) は東西共にバレル・ヴォールトが使用され、Pherrai (17) では東西共にドームが設けられている。A mphisa (34) では東側は クロス・ヴォールトなのに対し、西側はドーム・ヴォールトとなる。 Type-G の遺構では、東側のコーナーベイにバレル・ヴォールトが使

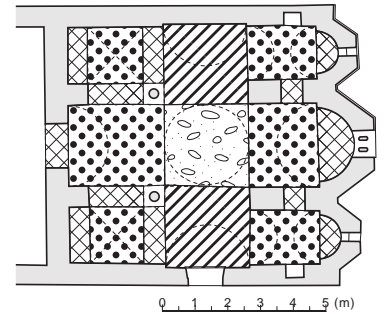

b. Melida(70; Type-G)

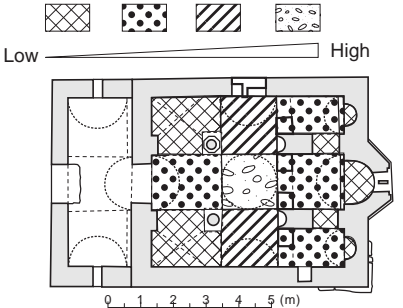

c. Lygourio(49; Type-H)
Fig. 8 P rocedure of ceiling construction (Type- $\mathrm{F}-\mathrm{H}$ )

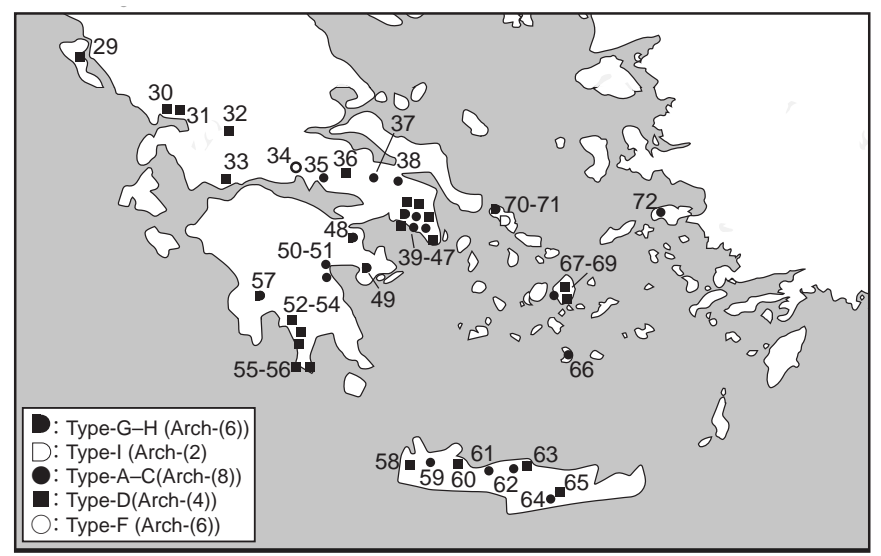

Fig. 9 Distribution of churches of Type-F-I and other types

用され、西側のコーナーベイにはそれぞれ全て異なる天井面架構が 使用されており、A. Iōannēs Theologos (44) はバレルヴォールトが使 用され、Panagias Katholikon (48) では、四半円ヴォールトが用いられ る。Samari (57) では、ドーム・ヴォールトが設けられ、M elida(70) では、 クロス・ヴォールトが用いられている。Type-H の遺構では、西側の 天井面架構はクロス・ヴォールトになる。従って Arch-6 型のうちで 東西のコーナーベイの天井面架構が同じとなる遺構は、A tik M ustafa Paşa (2) と Pherrai (17) のみである。またArch-6 型の遺構では、A tik M ustafa Paşa (2) では隅部柱は全て L 字だが、それ以外の 7 棟は、西 側の隅部柱が円柱を使用し、東側は矩形の柱を用いている。

これらの遺構の天井面の構築順序をみると、Type-F の場合、まず 横断アーチと東端の半ドームを構築し、その後にコーナーベイと十 字部の天井面を別々に構築したものと考えられる (Fig. 8-a)。一方、 Type-G-H の場合、共に教会堂の東側半分では、東べイとコーナー ベイ部の接続部に横断アーチを構築し、その後にコーナーベイと東 西べイの天井面を設けている。西側半分については、Type-G では西 ベイと西側のコーナーベイに別々に天井を設け (Fig. 8-b)、Type-H で は西側のコーナーベイを設けた後に西ベイの天井を設ける (Fig. 8-C)。 その後に南北ベイの天井面が設置される。

以上より、Arch-6 型の教会堂のうち、Type-F の教会堂では、 Type-A-B と同様に十字式構築となる。対して、Type-G の教会堂 では、教会堂の西半分は Type-A-B と同様に十字式構築となり、東 半分はArch-4 型と同様にドームバシリカ式構築となっているとい え、Type-H の教会堂では、教会堂の西半分は Type-C と同様に集中 式構築となり、東半分は Arch-4 型と同様にドームバシリカ式構築と なっているといえる。ここでType-G-H の 5 棟の地理的な分布をみ ると、Arch-8 型の遺構と Arch-4 型の遺構との交接地域に位置して 


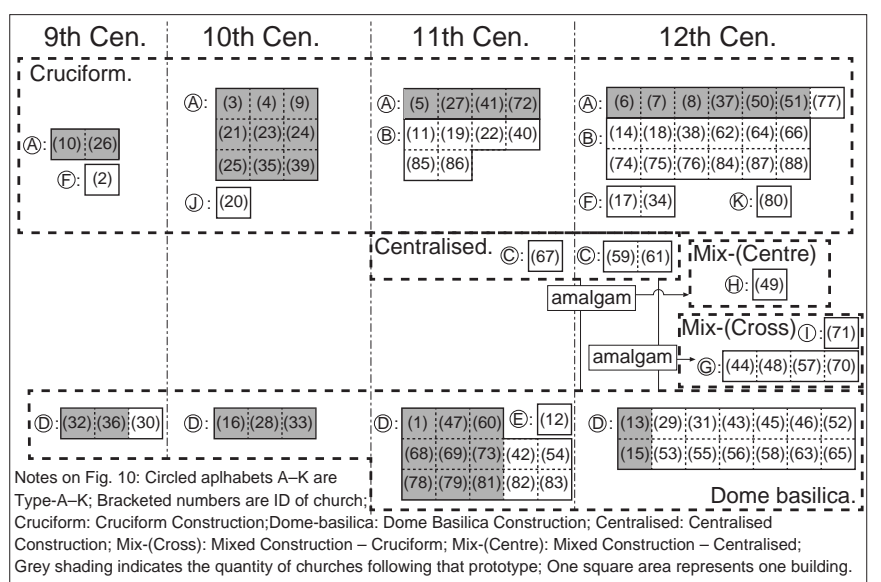

Fig. 10 Diagram of chronological changes in construction

いるといい得る（Fig. 9)。従って、これら 5 棟はArch-8 型と Arch-4 型との混淆とも捉え得ることができ、Type-G のような構築順序とな る場合、混淆式構築（Mixed Construction - Cruciform）とし、Type-H のような構築順序となる場合、擬混淆式構築（Mixed Construction Centralised）とする。

Arch-2 型 (Type-I) • Arch-2' 型 (Type-J ) - Wall 型 (Type-K) :

Type-I-K に該当する遺構はそれぞれ 1 棟ずつであり、Type-Iの M esaria (71) と Type-K の Nerezi (80) は 12 世紀創建、Type-J の Lavra Katholikon (20) は 10 世紀創建である。それぞれの遺構における横断 アーチの使われ方と隅部柱の断面形状をみると、Type-Iでは東側の コーナーベイには二つの横断アーチが使用され、西側のコーナーベ イには一つの横断アーチが使用されている。その隅部柱は、西側は 円形断面となり、東側は矩形断面となる。Type-Jでは、全てのコーナー ベイに二つの横断アーチが使用されている。その隅部柱は、東西と もに複雑な形状の多角形である。Type-K では東側のコーナーベイに は二つの横断アーチが設けられているが、西側のコーナーベイには 十字部との開口は設けられていない。その隅部柱は西側は L 字とな り、東側は矩形となる。それぞれのコーナーベイの天井面をみると、 Type-Iでは、西側がバレル・ヴォールトとなり、東側がドーム・ヴォー ルトとなる。Type-J では、西側はクロス・ヴォールトとなり、東側 はドーム・ヴォールトとなる。Type-Kでは、東西共にドームとなる。

それぞれの遺構の天井面の構築順序をみると、Type-Iでは、教会 堂の東側半分では、まず東側のコーナーベイに二つの横断アーチを 設け、東ベイと東側のコーナーベイに別々に天井を設ける。西側半 分では、西ベイとコーナーベイ部の接続部に横断アーチを構築し、 その後にコーナーベイと東西ベイの天井面を設ける。これらの後に 南北べイの天井面が設置される。Type-Jでは、まず横断アーチと東 端の半ドームを構築し、その後にコーナーベイと十字部の天井面を 別々に構築したものと考えられる。Type-Kでは、横断アーチと東端 の半ドームおよび西側のコーナーベイと十字部との間の壁を構築し、 その後にコーナーベイと十字部の天井面を別々に構築したものと考 えられる。

以上を踏まえると、Arch-2 型の教会堂は、教会堂の東側は Arch-8 型と同様に十字式構築となり、西側は Arch-4 型と同様にドームバシ リカ式構築となっており、その所在地からしても (Fig. 9)、Arch-8 型 と Arch-4 型とを、Arch-6 型とは東西逆に混ぜ合わせたものと捉え得

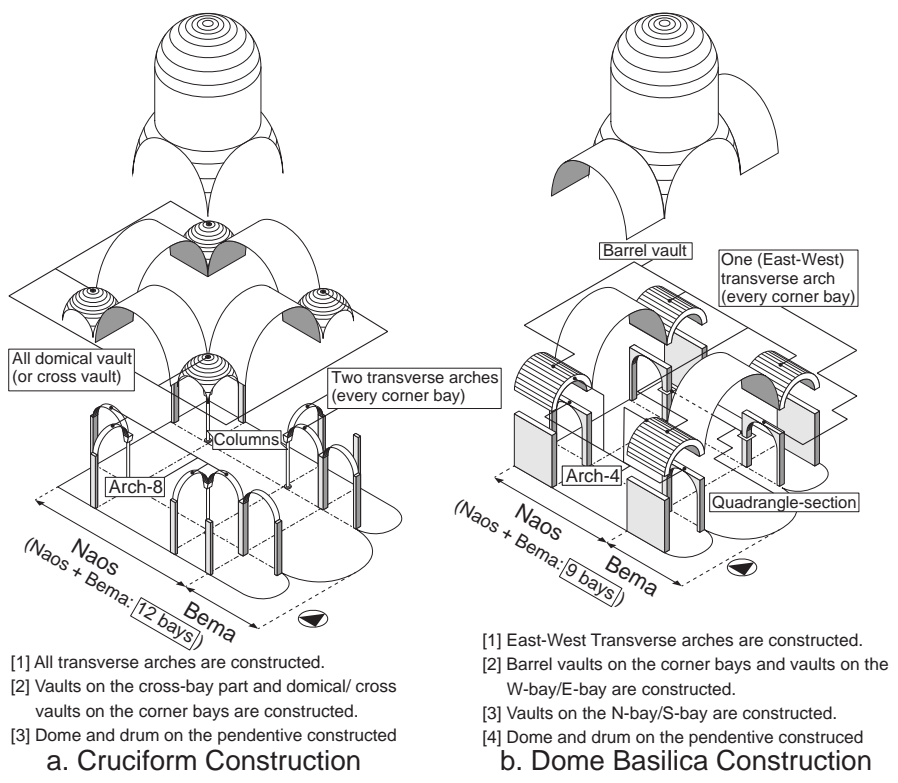

Fig. 11 Diagrams of Prototypes

る。一方、Arch-2' 型および Wall 型の教会堂は、Arch-8 型同様に十 字式構築と見做し得る。

\section{4-2. 天井面架構の構築順序の経年的な変化}

以上より、中期ビザンツ文化圏の内接十字型について、その内部 の構築順序に着目した結果、その展開について以下のことがいえる (Fig. 10)。

まず 9 世紀から 10 世紀の教会堂は、十字式構築とドームバシリカ 式構築という二つの構築順序によって構築されている。前者に該当 するものとして、Type-A の教会堂、Type-F の A tik M ustafa Pașa(2) お よびType-J の Lavra Katholikon(20) があり、後者に該当するものと して、Type-D の教会堂があげられる。これらの教会堂では、Lavra Katholikon (20) を除いて、四つのコーナーベイの天井面に同じ架構要 素を用いている。従って、A tik M ustafa Paşa(2) や Lavra K atholikon(20) のような例外もみられるものの、大多数を占める Arch-8 型と Arch-4 型の教会堂では以下のような典型（P rototype）が存在するといえ る。即ち、Arch-8 型では、全体が 12 ベイから構成され、各コーナー ベイに二つの横断アーチを設け、コーナベイの天井面架構はクロ ス・ヴォールトないしドーム・ヴォールトのいずれかに統一され、 ドームベイ隅部に円形断面の柱を使用する（十字式構築の典型：Fig 11-a）のに対し、Arch-4 型では、全体が 9 ベイで構成され、各コーナー ベイには一つの横断アーチしか設けず、コーナーベイの天井面架構 は全てバレル・ヴォールトとなり、ドームベイ隅部に矩形断面の柱 を使用する（ドームバシリカ式構築の典型：Fig. 11-b)。

続く 11 世紀についても、9〜10 世紀同様に十字式構築とドーム バシリカ式構築の二つの構築順序がみられる。しかし、9〜10世紀 では、Arch-8 型とArch-4 型の教会堂の架構構成が葟定型しかみ られなかったのに対し、11 世紀ではそのような定型から外れる教会 堂が増加してくる。即ち、Arch-8 型では、これまでみられなかった Type-B-C のような 9 ベイの教会堂が多数を占めるようになり (7/11 棟)、コーナーベイの天井面架構にこれまでは使用されてなかった ドームを用いる教会堂（Stilo (86), Rossano (85)）や横断アーチを設 
けずにコーナーベイの天井面架構を斜交ヴォールトにした Chalki Geōrgios (67) のような教会堂が出現し、ドームベイ隅部に矩形断面の 柱を使用する教会堂もみられるようになる。さらには、10 世紀まで にはみられなかった集中式構築の構築順序となる Chalki Geōrgios (67) のような教会堂もみられるようになる。また Arch-4 型の教会堂につ いても、Type-E が出現すると共に、西べイとコーナべイの間に開口 を設けないA. Theodoroi (47) や隅部柱が円形断面となる A. Asōmatoi (42) や Castro (83)、および西側の隅部柱が円形断面となり、東側は矩 形断面となるVambaka (54) のような教会堂もみられるようになる。

最後に 12 世紀についても、十字式構築とドームバシリカ式構築の 二つの構築順序は依然としてみられ、集中式構築の構築順序の遺構 も継続してみられる。十字式構築の遺構では、これまでみられなかっ たコーナーベイにバレル・ヴォールトを用いる教会堂や南北のコー ナーベイでことなる天井面架構となる教会堂もみられるようになる。 さらに Type-F の A mphissa(34)のように、西側の隅部柱が円形断面と なり、東側は矩形断面となる教会堂や Type-K の Nerezi(80) のように、 西側のコーナーベイと十字部との間に開口が設けられない教会堂も みられるようになる。ドームバシリカ式構築の教会堂では、11 世紀 までにみられなかった構成となる遺構はみられないものの、9〜11 世紀を通じて多数を占めていたドームバシリカ式構築の典型となる 遺構は 14 棟中 2 棟しかみられず、それ以外の教会堂では、いずれか の架構形式が典型とは異なっている。

加えて 12 世紀では、これまでの構築順序と異なる遺構もみられる ようになる。これらは、Type-G の遺構や Type-I の M esaria(71)によ うに、混淆式構築となる教会堂、Type-H の Lygourio(49) のように擬 混淆式構築となる教会堂である。混淆式構築および擬混淆式構築の 遺構のコーナーベイをみると、東西の一方のコーナーベイにはバレ ル・ヴォールトを使用し、もう一方のコーナーベイには、クロス・ ヴォールト、ドーム・ヴォールト、バレル・ヴォールト、四半円ヴォー ルトのような多様な架構要素を使用している。これらの遺構は全て ドームベイの西側隅部にのみ円形断面の柱を使用している。

このように、中期ビザンツ文化圈の内接十字型教会堂は、9〜12 世紀を通じて、十字式構築とドームバシリカ式構築という二つ異な る構築順序によって構築された教会堂が多数を占めており、特に 9 〜 10 世紀では、それぞれの構築順序ごとに典型と呼ぶべき架構構成 がみられた。しかし、この架構構成は 11 世紀以降次第に崩れていき、 構築順序そのものが従来とは異なる集中式構築 (11 世紀以降) や混 淆式構築 (12 世紀)、擬混淆式構築（12 世紀）による教会堂も出現 するようになる。そして、二円柱式内接十字型は、それまでの典型 的な架構構成の一部の架構形式を変化させたものと、異なる構築順 序を組み合わせたものという、いくつかの異なる様相の元に断続的 に出現したといえよう。

\section{5. まとめ}

中期ビザンツ文化圈における内接十字型教会堂建築について、内 部の構築順序に着目して分類した結果、以下の 3 点を指摘すること ができる。

9〜 12 世紀を通じて、中期ビザンツ内接十字型の天井面の構築順 序には主要な二つの構築順序が存在している。即ち、各べイの接続 部に横断アーチを設けることにより、コーナーベイと十字部とを別々
に構築可能な十字式構築と、東西方向にのみ横断アーチを設けるこ とにより、コーナーベイの天井面を構築しなければ十字部の天井べ イを構築できないドームバシリカ式構築である。構築順序から判断 すると、前者は十字部にコーナーベイが付属した集中形式的な発想 のもとに構築されていると捉えられるのに対し、後者は三廊式バシ リカの側廊の中央部のヴォールトを $90^{\circ}$ 回転させて、十字状にバレ ル・ヴォールトを配置し、その交点にドームを設けたものと捉えら れる。上部アーチの配列形式が前者では Arch-8 型となり、後者では Arch-4 型となることから、これら二者は、先稿における二つの系統 と大凡一致するといえる。

続いて、これら二つの構築順序以外に、11 世紀には十字式構築と 構築順序は類似しているものの、横断アーチを使用せずにまずコー ナーベイの天井面を構築し、その後に十字部の天井面を構築する集 中式構築、および教会堂の東西で十字式構築とドームバシリカ式構 築を組み合わせた混淆式構築や集中式構築とドームバシリカ式構築 を組み合わせた擬混淆式構築の構築順序となる教会堂もみられるよ うになる。混淆式構築と擬混淆式構築の構築順序となる遺構の分布 をみると、十字式構築の教会堂とドームバシリカ式構築の教会堂の それぞれが多く見られる地域の交接地域にみられることから、これ らの構築順序は十字式構築の教会堂とドームバシリカ式構築の教会 堂の双方の影響のもとに両者が交わってできたものと考えられる。

最後に、十字式構築の教会堂とドームバシリカ式構築の教会堂は、 9〜10世紀においては、一定の典型としての架構構成が窥えるのに 対し、11 世紀以降次第にその典型から逸脱した架構形式を有する教 会堂が増加していく。そして、二円柱式教会堂には、あくまで架構 形式の変化の一つとして、架構構成が多様化していく中で発生した であろう教会堂と混淆式構築や擬混淆式構築のように施工の手順の 変化によって発生したであろう教会堂とが存在しているといえる。

このように、内接十字型の教会堂では、断続的にさまざまな架構 構成が発生しつつも大きな二つのまとまりが存在し、相互に影響を 及ぼしあっていたものであろうと考えられる。このような架構形式 の変化と影響の波及に関しては、具体的な創建場所に着目しつつさ らなる検討を行う必要があると考えられることから、次稿以降での 課題としたい。

\section{謝辞}

本研究は、JSPS 科研費 17J08407 の助成を受けたものです。

注

1) 通例、暗黒期 (Dark Ages: Ćurčić など) ないし変革期 (Transitional period: Ousterhoutなど）と呼ばれる、7 世紀初頭のイスラーム帝国の勃興やバル カン半島へのスラヴ民族の侵入に代表される外患、およびビザンツ帝国内 でのイコノクラスム運動による内憂によってビザンツ建築が医とんど現存 しない時代。研究者によって多少のばらつきもあるものの、600 年頃から 800 年頃までを指す。Cf. Slobodan Ćurčić, Architecture in the Balkans: From Diocletian to Süleyman the Magnificent (New Haven: Yale University Press, 2010), 249-51; Robert Ousterhout, Master Builders of Byzantium (Princeton: Princeton University Press, 1999), 7.

2) Cyril M ango, Byzantine Architecture (1978; repr., Milan: Electa Editrice, 1985), 9.

3) Gabriel Millet, L'école grecque dans l'achitecture byzantine [The Greek School of Byzntine Architecture (in French)] (Paris: Ernest Leroux, 1916), 54-94; A nastsios

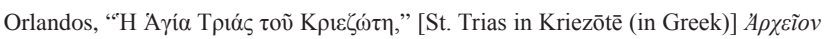

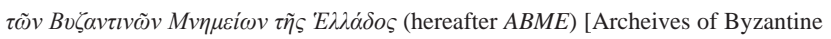


Monuments in Greece] 5 (1939-1940): 3-16.など

4）前稿同様に本稿でも、内接十字型をこのように定義する。Cf. Ryo Higuchi and Satoshi Nasu, “「内部架構構成からみた中期ビザンツ文化圈内接十字型 教会堂建築の成り立ち」[The Development of the Cross-in-Square Church in the Middle Byzantine Period in terms of its Architectural Configuration (in Japanese)]," 『日本建築学会計画系論文集』[Journal of Architecture and Planning] 737 (2017): 1818-20.

5) Higuchi and Nasu, "Cross-in-Square," 1817-27.

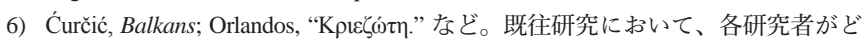
のようにコーナーベイ部の天井面の建築的な形態に着目してきたかについて は、前稿 Fig. 3 を参照のこと。Cf. Higuchi and Nasu, “Cross-in-Square,” 1819.

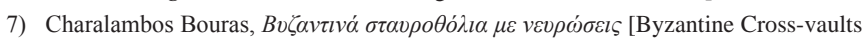
with lib (in Greek)] (Athens: Dēmosieumata tou achaiologikou Deltiou; 1965).

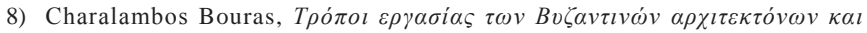
$\alpha \rho \chi \imath \mu \alpha \sigma \tau o \rho \omega \nu$ [M ethods of Work of Byzantine A rchitects and Chief-M asons (in Greek)] (Athens: Akadēmia Athēnōn; 2010); Ousterhout, M aster Builder.

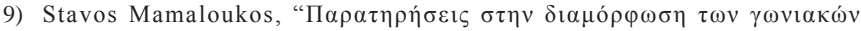

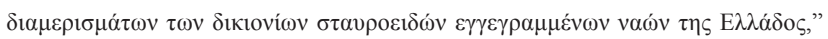
[Observations on the Form of the Corner Bays in Two-Columned Cross-in-Square

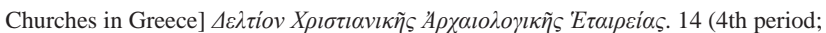
1989):198-204

10) Richard K rautheimer, Early Christian and Byzantine Architecture, 4th rev. (New Haven: Yale University Press, 1986), 390-92.

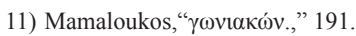

12) Ćurčić, Balkans, 329.

13) 本稿における内接十字型が既往研究のどのような用語に対応するか、およ び内接十字型が出現した初期の遺構の教会堂については前稿注 3 を参照の こと。Cf. Higuchi and Nasu, "Cross-in-Square," note 3.

14) 例えば、Millet, L'ecole など

15) Ćurčić は、内接十字型が直線的に発展してきたという、これまでの既往研 究が間違いだと指摘しつつも、自身の研究における教会堂の年代推定には、 これまでの既往研究と同様な、直線的な発展を推定しているように見受け られる。例として、Kaynarca(1) の教会堂について、引用元の M amaloukos の研究では 10-11 世紀創建と推定しているにも拘らず、Ćurčić は 9-10 世 紀創建と推定しており、創建年代を変更した特別な根拠は特に示していな い。Kaynarca(1) の教会堂を含め、Ćurčić の研究では、隅部柱が矩形断面 の教会堂は得てして創建年代が早目に推定され、円形の教会堂は遅めに

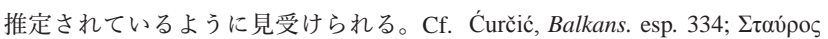

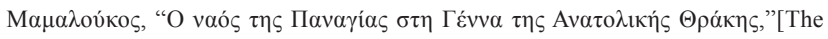

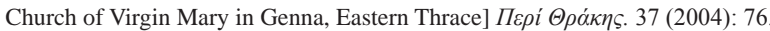

16) M ango, Byzantine Architecture, 9-11, 174-78.

17) Oskar Wulff, Die Koimesiskirche in Nicäa und ihre Mosaiken nebst den verwandten kirchlichen Baudenkmälern [K oimesis Church in Nicaea and its M osaics with Related Church Monuments (in German)] (Strassburg: J. H. E. Heitz, 1903), 91, 94. など

18) 本稿では、内部空間に着目することから、天井とは教会堂の内部空間を上 端を構成する水平な要素のうち、その下部に人が下部を移動できるものの みを扱い、教会堂にしばしば設けられる、小さなニッチなどに関しては特 に扱わず、また内部と外部との開口部に関しては検討は行わない。

19) 中期ビザンツ内接十字型教会堂の選定にあたっては、以下の書籍を使用し

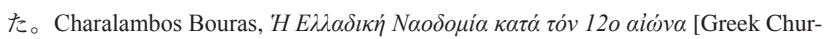
ches in 12th Century (in Greek)] (Athens: Emporikē Trapeza tēs Ellados, 2002);

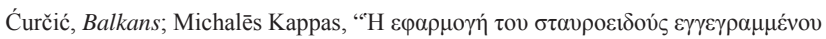

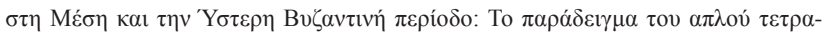

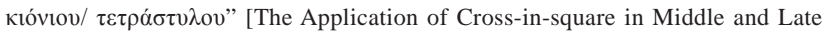
Byzantine Period: The Example of Simple Four-column/ four-pier (in Greek)] (PhD diss., A ristotle U niversity of Thessaloniki, 2009); K rautheimer, Early Christian;

20) 上部架構まで検討可能と考えられる 124 棟について、各世紀ごとの内訳を
みると、 9 世紀が 6 棟、10 世紀が 15 棟、11 世紀が 38 棟、12 世紀が 65 棟 であり、そのうち本論にて検討対象とする 88 棟の遺構は、9 世紀が 6 棟 (100\%)、10 世紀が 13 棟（86.7\%)、11 世紀が 25 棟（65.8\%)、12 世紀が 44 棟 $(67.7 \%)$ である（括弧内の比率は、検討可能な内接十字型の遺構に 対する本論で検討対象とする遺構の割合を示す)。なお、推定創建年代が 9 〜 10 世紀のように複数の世紀にわたる遺構については、推定創建年代中で 最も新しい世紀に創建されたものとしている。ただし、検討対象年代（800 ～ 1204 年）において 13 世紀は 4 年間しか無く、創建年ないし推定創建年 が 1201 ～ 1204 年の範囲にのみ収まる遺構は認められないことから、推定 創建年代が 13 世紀にまで亘る遺構の推定創建年代について煩雑さを避ける ため 12 世紀とした。また、表中のID は、対象遺構について、現在の国ご とかつ中期ビザンツ期の行政区画ごとに北から割り振ったものであり、教 会堂の呼び方については、同じ名称となる場合や名称不明のものが存在す ることから、本稿では通常遺構の存在する地名を使用し、同じ場所に複数 の遺構が存在する場合には、遺構の名称と地名の双方を使用している。

21) 前稿同様に本論文では、ナルテクスについては扱わない。Cf. Higuchi and Nasu, "Cross-in-Square," 1818-19.

22) 前稿では、ベイ (bay) は字義通り柱間とした。しかし本稿では、天井面を 分析することから、柱間に着目しつつも、その天井面が架構要素ごとに分 節可能かにも着目し、両者が異なる場合については、天井面架構の分節の 有無を優先し、これを便宜的にベイと呼ぶ。Cf. Higuchi and Nasu, “Cross-inSquare," 1821.

23) 各部の英語名称については、以下の書籍を参考にしている。Cf. Sophia Kalopissi-Verti and M aria Panayotidi-K esisoglou, eds., Multilingual Illustrated Dictionary of Byzantine Architecture and Sculpture Terminology (Herakleion: Crete University Press, 2010).

24) 例外的な架構要素として、Arta A. Dimitōrios（30）では、西側の偶部柱か ら南北へ水平な材が渡されている。教会堂自体の来歴には不明な点が多く、 この部分が創建当初のものなのか後代の改修によるものか判別しがたい。 しかしこの部分は戸枠によるものでは無く、戸枠を除くと中期ビザンツの 建築物において、教会堂内部の開口を水平とするものは、それが桓であれ フラット・アーチであれまずみられないことから、当該部分とその上の垂 れ壁について本稿では後代の改修によるものと見做す。

25) 半ドームはまた、北べイの北端および南べイの南端に設けられる半円平 面のアプスと呼ばれる部位の天井面にも設けられる。このような教会堂 は一般にアトス型と呼ばれ、対象遺構のうちでは、Lavra K atholikon (20), Vatopedi Katholikon (21), Iviron Katholikon (23), X enophontos K atholikon (25)) が該当する。しかしこれらの遺構では、Vatopedi Katholikon (21) を除いて南 北のアプスは創建当初のものでは無い。

26）なお実際には、内接十字型の上部は、これら天井面架構のように水平面を 構成する要素に加えて、垂れ壁のような垂直面を構成する要素 (ドラムなど) も随時使用される。しかし、これらは全て水平面を構成する要素の上に載 る構成となり、施工順序に着目する場合には水平面を構成する要素の上下 関係について考慮すれば十分であると考えられる。

27) Higuchi and Nasu, "Cross-in-Square," 1824-25.

28) 註 24 で指摘した通り、Arta A. Dimitōrios（30) では、西側の偶部柱から南 北へ水平な材が渡されているが、本稿では当該部分を後代の改修による元 と見做しており、これを除いて考えると、当該教会堂は Arch-4 型の同様の 架構形式となる。

29) なお、対象遺構については、A. Theodoroi (47) や Nerezi(80)のように、十字 部とコーナーベイ部との全ての接続面に開口が設けられない教会堂もみら れるが、このような教会堂に関しても、便宜上壁では無く隅部「柱」として、 捉えて分類している。

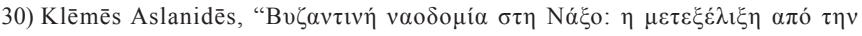

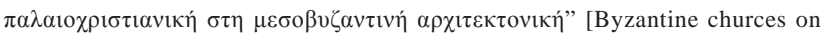
Naxos: the evolution from early-christian to middle-byzantine architecture (in Greek)] (PhD diss., University of Patmos, 2014), 207-8. 


\author{
Ryo $\mathrm{HIGUCHI}^{* 1}$ and Satoshi NASU ${ }^{* 2}$ \\ ${ }^{* 1}$ Doctoral Course, Tokyo Institute of Technology, M.Eng. \\ *2 Assoc. Prof., Tokyo Institute of Technology, Dr.Eng.
}

Middle Byzantine architecture obtains its character from certain unique characteristics different from those of early Byzantine architecture. The objects of attention in this paper, the so-called 'cross-in-square' church has, constructed from the late 8th century, representing a characteristic example of the Middle Byzantine architecture. However, although previous typological studies have identified many different types of cross-in-square church, they did not focus on the relationships between these types. Therefore, the chronological development of the cross-in-square is still largely unexamined. Following its predecessor, this paper refers to each bay using the terminology defined in Fig. 2 and addresses 88 churches (Fig. 1; Table 1) for which three-dimensional information is available and examines how the architectural configuration changed chronologically during the Middle Byzantine period. The specific focus of this paper is to identify the different procedures used to construct ceilings in these churches, in terms of the sequence of elements constructed, and to establish the historical trajectory by which these procedures evolved and diversified.

First, this study shows all types of ceiling shapes presented in the cross-in-square churches: dome, pendentive, squinch, conch, barre vault, half-barrel vault, cross-vault, diagonal intersecting vault, domical vault and arch (Fig. 3). The cross-in-square churches are made of combinations of these shapes. The arches between cross-bay areas and corner bay areas where the arch does not continue into the corner bay ceiling are called 'transverse arches'.

Then, we categorise the churches into 10 types according to the arrangement of the arches and the number of the highest arches (Fig.4), according to the numbers of transverse arches in each bay (Fig. 5) and based on the number of bays in the Naos and Bema areas of the church (Fig. 2). These types are further grouped according to two principal procedures followed when constructing ceilings for the $\mathrm{N}$ aos and Bema in these churches, based on similarities that persist throughout the Middle Byzantine period. One procedure constructs the transverse arches first, then the ceilings of the corner bays and the ceilings of NSEW-bays (Cruciform Construction); the other order first sets the east-west transverse arches, then the ceilings of the corner bays and the EW-bays, and finally the NS-bays (Dome Basilica Construction). Beginning in the 11th century, another construction procedure similar to Cruciform Construction appears, which is first to construct the ceilings of the corner bays and then the ceilings of the NSEW-bays (Centralised Construction). Two mixed construction procedures appear in the 12th century: Cruciform Construction and Dome Basilica Construction (Mixed Construction - Cruciform) and Centralised Construction and Dome Basilica Construction (Mixed Construction - Centralised) (Fig. 10).

Among these, Cruciform Construction and Dome Basilica Construction each follow a fixed architectural configuration, which can be regarded as a prototype. Cruciform Construction, features eight arches at the maximum height (Arch-8), a total of twelve bays in the Naos and Bema, each corner bay has two transverse arches, the ceilings of the corner bays are cross-vault/domical-vault and the supports under the domes are columns. Dome Basilica Construction is identified with four North-South arches at the maximum height (Arch-4), a total of nine bays in the Naos and Bema, and each corner bay having a single East-West transverse arch; the ceilings of corner bays are barrel-vaulted and the supports under the domes are quadrangle-section piers. However, these prototypes become less clearly defined during the 11th century and other construction procedures appear, such as Centralised Construction, Mixed Construction - Cruciform and Mixed Construction - Centralised. Additionally, two-columned cross-in-square churches appear in several different permutations, which involve changing the architectural configuration within the same construction order, in some cases, or combining different orders of construction in others. 